\title{
Opinions of Pre-Service Teachers about Evolution
}

\author{
Ayla Karataş \\ Correspondence: Ayla Karataş, Kocaeli üniversitesi, Faculty of Education, Turkey. \\ Received: March 12, 2019 \\ doi:10.11114/jets.v7i8.4284 \\ Accepted: April 28, $2019 \quad$ Online Published: May 21, 2019 \\ URL: https://doi.org/10.11114/jets.v7i8.4284
}

\begin{abstract}
Evolution is a cornerstone that combines all sub-branches of biology in a meaningful way. Developing a true understanding of evolution, however, can only be achieved through comprehensive education. In the community, teachers have an important role in removing erroneous attitudes toward evolution, in which science and biology teachers have a key role. This study aimed to reveal pre-service teachers' perspective on evolution by eliciting the opinions of science pre-service teachers who had attended a 14-week evolution course and those who had not yet taken this course using a delimited draft sentence. According to the data, students who had limited knowledge about evolution, either dogmatically rejected evolution or defined evolution in a simple way, as a change. The rate of rejecting the concept of evolution was decreased among the students who had taken the course about evolution. In addition, there was an increased ratio of those who described evolution using high-level knowledge and a non-rejecting style. Another interesting outcome mentioned in the statements of the students was that keeping the content of the course as wide as possible reduced prejudice against the concept of evolution, decreased rejection rate, and also allowed students to change the erroneous/incorrect ideas that they previously held about evolution.
\end{abstract}

Keywords: education of evolution, pre-service teachers, prejudice against evolution

\section{Introduction}

Darwin summarized evolution as "all the organic beings which have ever lived on this planet, have their origin from a primitive form". Evolution is the most striking and significant theme of the living world, seeking answers to the questions where life emanates from, why there are so many different organisms, and explaining the reasons for the diversity and unity of living creatures (Freeman, \& Herron, 2002; Dobzhanzky, 1973). It is not possible to understand modern biology without comprehending evolution because it is the only theory that unites all fields of biology, from molecular biology to ecology (Futuyma, 2008; Lerner, 2000; Tidon, \& Lewontin, 2004).

Although evolution is a cornerstone that combines all sub-branches of biology in a meaningful way, it is also a controversial issue. Research shows that there are conflicts and controversial opinions on this topic in almost every country in the world (Blackwell, Powell, \& Dukes, 2003; Glaze, \& Goldston, 2015a; Thagard \& Findlay, 2010), and the concept is usually rejected (Tidon, \& Lewontin, 2004; Barnes \& Brownell, 2016; Alters, \& Nelson 2002). The broad-based research of Miller, Scott, and Okamoto (2006) showed that the tendency to accept evolution is higher in Europe compared to other parts of the world, such as Turkey, USA, and Cyprus. Hameed's (2008) research conducted in Muslim countries revealed that the acceptance of evolution was 22\% in Turkey, 16\% in Indonesia, 14\% in Pakistan, $11 \%$ in Malaysia, and $8 \%$ in Egypt, increasing to $40 \%$ in Kazakhstan. In another study, it was reported that evolution was also a controversial topic in science education in America, and there were objections against teaching all or part of the theory of evolution in public schools at elementary and secondary education level. According to Lerner (2000), this dispute is not really scientifically based, but rather it is related to religion and politics (Lerner, 2000). There are few issues, such as evolution leading to such conflicts in society although they do not really interfere with moral values. None of the topics covered in physics, chemistry, and biology attracts the attention of society as the theory of evolution. An underlying reason of the prejudice in the community against the concept of evolution is that unfortunately, it is not understood well (Alters, \& Nelson 2002), because this topic is not adequately taught at various educational levels for a variety of reasons. Indeed, Nadelson and Southerland (2012) stated that evolution was misunderstood all over the world, especially because the scientific explanations presented by individuals who are not experts in the field.

To understand evolutionary biology requires engaging in other disciplines, such as geology, mathematics, and philosophy, in addition to deep knowledge in various fields of biology. This knowledge in these fields, which has been 
specialized by professionals, is often inaccessible; thus, it is the role of the teacher to transfer this knowledge (Tidon \& Lewontin, 2004). The teaching of the theory of evolution in classes is largely dependent on biology teachers and their personal decision-making mechanisms (Dee Goldson, \& Kyzer, 2009). Therefore, the instruction of evolution that is based only on scientific knowledge is related to the attitude of science and biology teachers. Teacher's perspective on evolution will be reflected in the format of the lesson, and hence it will determine the formation of the society on this matter. Various researchers have stated that students and teachers are influenced by the culture of the society in which they live and this influence has spread to the classroom (Mpeta, Villiers, \& Fraser, 2015; Abrie, 2010; Blackwell, Powell, \& Dukes, 2003; Deniz, Donelly, \& Yilmaz, 2008). A teacher's attitude toward evolution is determined by his knowledge of evolution and his view of evolution Thus, as stated by, Anderson (2007), teachers 'personal epistemologies and differences in the understanding of evolution can support students' intellectual development, but could also create a barrier to that development.

The studies about evolution are mostly focused on the understanding of the general public (Miller, Scott, \& Okamoto, 2006); however, there are few studies based on science teacher's acceptance and understanding of the theory of evolution (Deniz, Donelly, \& Yilmaz, 2008; Rutledge, \& Warden, 2000). Glaze, Goldston and Dantzler (2015b) commented that the number of studies about evolution, conducted with science pre-service teachers was quite low. It has been found that in addition to the cognitive knowledge level of the teachers (Glaze, Goldston, \& Dantzler, 2015b; Deniz \& Şahin, 2016; Deniz, Donelly, \& Yilmaz, 2008), their personal beliefs and worldviews are also effective in shaping their perspectives on evolution (Blackwell, Powell, \& Dukes, 2003). Teachers' level of acceptance of evolution is usually low and even having a higher level of education (master's degree) does not change their perspective on evolution (Nunez, Pringle, \& Showalter, 2012). Various studies revealed that the negative view concerning evolution is associated with understanding of the nature of science, level of conceptual knowledge about evolution, religious views and the beliefs of science teacher (Glaze, \& Goldston, 2015a). However, it was revealed that biology pre-service teachers' religious beliefs, conceptual knowledge level, and open-mindedness are effective on accepting the theory of evolution (Deniz, \& Şahin, 2016; Deniz, Donelly, \& Yilmaz, 2008), and there is a positive relationship between understanding and accepting evolution (Nunez, Pringle, \& Showalter, 2012). In their research conducted with science and biology pre-service teachers, Apaydın and Sürmeli (2009) found that the attitude toward evolution was low. Kim and Nehm (2011) analyzed the opinions about evolution of pre-service teachers in South Korea and compared them with American science teachers, finding that the former had lower evolutionary acceptance than the latter.

The teacher's acceptance and understanding of evolution may have significant effects on learning of students (Nunez, Pringle, \& Showalter, 2012). High-school teachers and especially teachers of the developing countries play an important role in spreading scientific perspective of evolution. Anderson (2007) stated that teachers' opinions and the assessment in teaching evolutionary concepts were important for making suggestions for different cultures and education systems.

The perspective of primary, secondary and high school teachers on evolution is an important factor in society's attitude toward this issue; thus, the knowledge level and positive perspective of teachers about evolution are reflected onto the student, and therefore society. Even though secondary education is part of compulsory education throughout the world, some students are not obliged to take biology-based courses. It is important to provide instruction on the basis and functioning of this topic within the content of middle school science course at an appropriate level. The current research is built on the opinions of pre-service science teachers, who will have an important role in the future between elementary and high school education, about the evolution. . In this research, a comparison was made between the views of pre-service teachers who had taken a comprehensive evolution course and those who had not taken this course. The majority of the research in the literature is related with the adoption of evolution (Taşkın, 2013; Miller, Scott, \& Okamoto, 2006), difficulties in teaching evolution, factors affecting the teaching of evolution, perceptions toward evolution (Glaze, \& Goldston, 2015), and perspectives of evolution (Deniz, Donelly, \& Yilmaz, 2008). This study used a qualitative research method to investigate whether a comprehensive evolution training changed the participants' perspective on evolution.

\section{Method}

In the qualitative research method used in this study, students' opinions were obtained with a gap-fill form. It was attempted to reveal the opinions of the pre-service teachers about evolution freely but in limited sentences. This was achieved by adopting two techniques from the literature, namely "free word association" (Kurt, Ekici, Aktaş, \& Aksu, 2013), and the "metaphor technique" (Y1lmaz, 2016).

A sentence pattern was designed, which enables students to freely reflect the clear and concise thoughts that they have about evolution and the foundation of these thoughts. The data were collected through a worksheet, in which the participants completed the following sentence, "In my opinion, evolution (is) .................., because ...........................". In test techniques, students have to select one of the options, whereas this method left the students' mind free to reveal their thoughts about evolution. 


\subsection{Participants}

Science education undergraduate students were selected for this study, because the perspective of pre-service science teachers is an indicator of the profile of future society. The data included in the analysis were collected from 190 students enrolled in the Science Education Program in the Mathematics and Science Education Department of Faculty of Education. All the students were Muslims. The evolution course was presented during the senior year of students in the education faculty.

A sample group was designed to determine the impact of the evolutionary course on students' views on evolution. For this purpose, data were collected from 91 fourth-grade students who had completed this course, as well as 99 from second- and third-grade students who had not taken this course for comparison (Table 1). The basic topics covered within the content of this course were the geological evolution process, importance of variations within a species, natural selection, functioning of natural selection, populations' genetics, factors that change population genetics (microevolution factors), concept of biological species and the barriers of speciation, geographic isolation and allopatric speciation, macro-evolution, sympatric species formation, speciation through autopolyploid and allopolyploid, and mutations, especially the mutation of developmental genes. This course is presented over a semester and takes 14 weeks to teach these basic topics.

\subsection{Data Analysis}

Using content analysis, the responses given by pre-service teachers were divided into nine basic themes evaluated under the following headings: "there is no evolution", "evolution is change", "evolution is the effort to understand the natural world", "evolution is the change of species/populations", "evolution is change through adaptation/natural selection", "evolution is the reason for diversity", "evolution is associated with genetics, and "I realized that I was misinformed about evolution". The data that could not be classified under these themes were placed in the "other" category.

Students' opinions were divided into three groups: refuser, superficial information, and deep knowledge (Table 1). Having opinions about the evolution of populations, interpreting evolution as an effort to understand the nature, mentioning species and population changes, explaining evolution for genetic reasons, or realizing that they are misinformed about evolution were high-level expressions. The words containing this information were classified as themes with a high level of information (Table 1).

\subsection{Validity and Reliability}

To ensure the validity of the study, the samples included both students having taken the evolution course and those who had not taken it. Thus, the diversity of the data was ensured, the opinions of both student groups were compared, allowing the reflection of different perspectives on the results (Merriam, 2009). In addition, in this paper, the sentences collected and classified from the students are presented as is so that the reader can view the raw data in direct quotations. In this way, readers are provided with the opportunity to determine their own conclusions and interpretations (Yıldırım, \& Şimşek, 2008; Merriam, 2009).

To ensure reliability, the sentences were classified by two researchers separately, and draft themes were determined. This step was repeated three times, and the final version of the themes was accepted after checking that the themes covered all data. The compliance ratio of the generated themes was calculated as $87.64 \%$. In a study of this type, a compliance percentage of $70 \%$ and above is considered to be an acceptable value (Miles, \& Huberman, 1994). Codes that were subject to disagreement were examined again, and upon consensus by researchers, the basic themes were established.

\section{Results}

The themes that were formed based on the sentences of pre-service teachers about the theory of evolution are given in Table 1 . An overview of the table clearly shows that the majority of the students who had not taken the evolution course either described evolution as a change or rejected the concept. On the other hand, it is apparent from the table that the rate of rejection decreased among the students who had completed the course. In addition, the students' sentences showed that they had some knowledge of evolution commenting on its association with genetics and emphasizing natural selection and population knowledge. More importantly, after the course, some students stated that they realized that they were misinformed about this concept. It can be said that the increase in academic knowledge about evolution reduced the rejection rate. In their sentences, 31 students used expressions that rejected evolution, of whom 29 had not taken the evolution course (Table 1), whereas only two of the students who had completed the course rejected the concept. A few examples of the sentences made by students on this issue are shown in the appendix (students 1-4).

The students' statements show that the acceptance of evolution was perceived as a conflict with the dominant belief system. Twenty-nine students of this group had not yet taken the course of evolution. The statements given were not related to a scientific inconsistency about evolution; they were more about the belief system. On the other hand, only 
two of the 91 students, who had taken the evolution course, gave statements that rejected evolution; indicating that academic knowledge accumulation reduces the prejudice about evolution.

Most of the students (27\%) who expressed evolution simply as a change were those that had not taken the evolution course. Some examples of the statements are shown in the appendix (students 5-8).

Table 1. Comparison of the opinions of the students who had taken the evolution course and those who had not taken the course

\begin{tabular}{|c|c|c|c|c|c|c|}
\hline \multirow[t]{2}{*}{ Groups } & \multirow[b]{2}{*}{ Themes } & \multicolumn{2}{|c|}{$\begin{array}{c}\text { Taken the evolution } \\
\text { course } \\
\text { (fourth-grade } \\
\text { students) }\end{array}$} & \multicolumn{2}{|c|}{$\begin{array}{l}\text { Not taken the evolution } \\
\text { course } \\
\text { ( second- and third-grade } \\
\text { students) }\end{array}$} & \multirow[b]{2}{*}{ Total } \\
\hline & & $\mathbf{N}$ & $\%$ & $\mathbf{N}$ & $\%$ & \\
\hline Rejecter & There is no evolution & 2 & 1.5 & 29 & 15.26 & 31 \\
\hline $\begin{array}{l}\text { Superficial } \\
\text { Knowledge }\end{array}$ & Evolution is change & 15 & 7.89 & 53 & 27.90 & 68 \\
\hline \multirow{7}{*}{$\begin{array}{l}\text { Deep } \\
\text { Knowledge }\end{array}$} & $\begin{array}{l}\text { Evolution is the effort to } \\
\text { understand the natural world }\end{array}$ & 23 & 12.11 & 0 & 0 & 23 \\
\hline & $\begin{array}{l}\text { Evolution is the change of } \\
\text { species/populations }\end{array}$ & 13 & 6.84 & 4 & 2.11 & 17 \\
\hline & $\begin{array}{l}\text { Evolution is change through } \\
\text { adaptation/natural selection }\end{array}$ & 9 & 4.74 & 8 & 4.21 & 17 \\
\hline & $\begin{array}{l}\begin{array}{l}\text { Evolution is the reason for } \\
\text { diversity }\end{array} \\
\end{array}$ & 11 & 5.79 & 0 & 0 & 11 \\
\hline & $\begin{array}{l}\text { Evolution is associated with } \\
\text { genetics }\end{array}$ & 8 & 4.21 & 2 & 1.05 & 10 \\
\hline & $\begin{array}{l}\text { I realized that I was misinformed } \\
\text { about evolution }\end{array}$ & 7 & 3.68 & 0 & 0 & 7 \\
\hline & Other & 3 & 1.58 & 3 & 1.58 & 6 \\
\hline Total & & 91 & 47.89 & 99 & 52.11 & 190 \\
\hline
\end{tabular}

Most of the students who had not taken the evolution course formed sentences that either rejected evolution or explained it in a simple way. The review of Table 1 shows that students who had not taken the evolution course were distributed in these two groups (15.26\% and 27.90\%). However, it was observed that the higher level of descriptions were given and the level of rejection decreased among the students who had taken the course, with the increase of their level of knowledge. This result seems to reveal that the increase in knowledge decreases rejection and reduces prejudice against the concept of evolution. Moreover, the increase in the descriptions that require high-level knowledge is shown in Table 1.

After that, some of the students provided an in-depth explanation for their views concerning evolution.

Evolution, being the effort to understand the natural world, was only mentioned by the students who had taken the evolution course and constituted $12.11 \%$ of the whole group (students 9-13). There was no such opinion presented by the students who had not taken the evolution course (Figure 1).

As can be seen from the students' statements of this group, "the effort to understand the natural world", which was mentioned only by the students who had taken the evolution course is a high-level interpretation. Interpreting evolution as the change of species/populations is another description requiring very high level of knowledge (students 14-16) (Figure 1). Of the students, $6.84 \%$ who made this comment were those who had taken the course. 


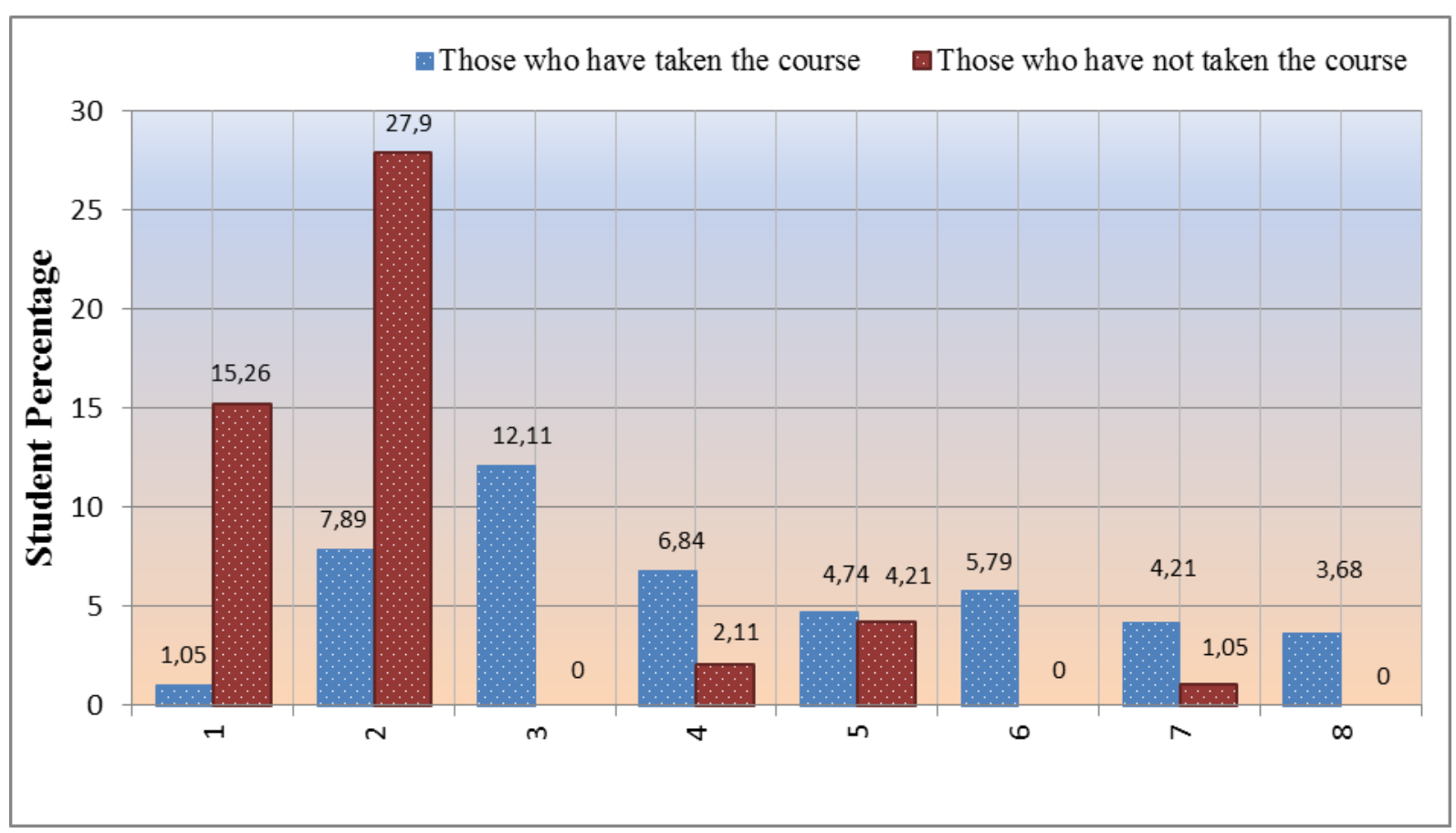

Figure 1. Themes formed according to the opinions of students

1. Rejecters; 2. Those who think that evolution is change; 3. Effort to understand the natural world; 4. The change of species/populations; 5. Change through adaptation/natural selection; 6. The reason for diversity; 7. Associated with genetics; 8 . Those who realized they were misinformed about evolution.

Understanding that evolution occurs in populations is an important infrastructure for the comprehension of evolution. The proportion of students having this idea increased after they had attended the evolution course.

Students who defined evolution as an outcome of natural selection and adaptation constituted $8.95 \%$ of all students, and the distribution of this ratio in terms of the students who had taken the course and those who had not was almost even (students 17-18) (Table 1). Some students who had not taken the course also explained evolution through natural selection and adaptation, which may show that these topics are presented within secondary education and are the most well-known issues concerning evolution (Figure 1).

The ratio of the students who defined evolution as the reason for diversity was $5.79 \%$, and this interpretation was only given by the students who had taken evolution course. Describing evolution as a reason for diversity is an interpretation requiring high-level knowledge (students 19-21).

The ratio of the students who associated evolution with genetics was $5.26 \%$, of which $4.21 \%$ comprised the students who had taken the evolution course. Examples of students' sentences are shown in the appendix (students 22-23).

In addition, $3.68 \%$ of the students stated that they were misinformed or had erroneous ideas about evolution, but these ideas were changed after taking the evolution course (Figure 1). According to examples of the students' sentences, it can be said that the increase of academic knowledge about evolution allowed both the correction of students' misinformation and reducing prejudice in relation to the concept of evolution (students 24-27).

In the current study, there were also student opinions that could not be classified under the above-mentioned themes. Examples of other interpretations, which formed 3.16\% of the sample, are shown in the appendix (students 28-29).

In addition, 12 students $(6.31 \%)$ commented on the evolution of human beings, but these comments were not suitable to be grouped under a single theme; thus, they are presented here independent of tables. Some pre-service teachers used expressions stating that evolution was only about human beings or was related to the ape-descendance of humans. The examples of these sentences, indicating that evolution is only about human beings, excluding the ideas, thoughts or questions about other living beings and their origin, are shown in the appendix (students 30-34). As can be understood from these examples, students tended to perceive evolution as human-focused. 


\section{Discussion}

According to the constructivist approach, the factors that affect the conceptual understanding of the students are their existing knowledge about the target issue. However, in the teaching of evolution, students' perspective on science and religion is added to their existing knowledge. It has been found that the opinions of the students who attend earth sciences or biology courses are quite suspicious, and this is reflected in the status of the whole population. Students have a tendency to believe that evolution theory is not correct without considering their lack of knowledge and ideas (Anderson, 2007). Indeed, in our research, the ratio of the pre-service teachers who completely rejected evolution was $16.31 \%$, and this finding is in line with the results reported by other researchers. Mpeta, Villiers and Fraser (2015) conducted research in South Africa and showed that $19.63 \%$ of the student participants rejected evolution. On the other hand, in our study, the largest part of this group was formed by the students who had not taken the evolution course. This supports the idea that the worldview of the individual is quite effective in terms of the acceptance of complex systems, such as evolution (Glaze, \& Goldston, 2015a; Glaze, Goldston, \& Dantzler, 2015b; Alters and Nelson, 2002). Teachers tend to have insufficient accumulation of knowledge about both evolution and teaching evolution; in addition, they possess conflicting opinions concerning evolution and their religious beliefs (Akyol, Tekkaya, Sungur, \& Traynor, 2012). Regarding the findings of this research, prevalent among students was the idea that believing in evolution was contradictory to religious beliefs. The statements of some pre-service teachers show that they perceive evolution and creation as alternatives and that if they accepted one idea, they would have to reject the other completely. The reason for this may be that in secondary education textbooks, evolution and creation theory are presented as alternatives (Apaydın, \& Sürmeli, 2009; Peker, Cömert, \& Kence, 2010), and during their secondary education, students might have gained the idea that only one of the two alternatives could be accepted. However, perceiving and accepting evolution as a scientific fact does not mean denying the Creator because evolution theory does not make such an inference. Evolution is related to the cognitive domain, whereas belief systems are related to the affective domain, and they are not related to each other. The idea that a non-believer should absolutely accept evolution is as absurd as the idea that a believer should completely reject evolution. A similar interpretation was also present by Mpeta (2015) in the statement that being religious or having a religious perspective does not mean that evolution could not be understood and accepted neither does accepting evolution mean that religious beliefs should be abandoned. In the current study, the rejection ratio dropped to $1.05 \%$ among the students who had taken the evolution course (Table 1), and this outcome shows the importance of comprehensive education concerning evolution. Thus, it can be said that adequate education and a satisfactory explanation of scientific data is effective in individuals' acceptance of evolution and reducing prejudice about evolution. Other researchers also reported that regarding the acceptance of evolution, there is a positive relationship between attitude and knowledge level; increased level of knowledge is leads to increased acceptance of evolution. (Lawson, \& Weser 1990; Rutledge, \& Warden 2000; Glaze, Goldston, \& Dantzler, 2015b; Deniz, Donelly, \& Yilmaz, 2008; Deniz, \& Şahin, 2016). Similarly, Rutledge and Warden (2000) identified a relationship between teachers' understanding of the theory and nature of science and their acceptance of evolution. Therefore, the outcomes of our research showing that the complete rejection of the evolution was lower among the students had taken the evolution course may indicate that the lack of knowledge is more effective in the rejection of evolution compared to the worldview of the individual. Anderson (2007) stated that according to the constructive approach, a science teacher should face the reality that students have different initial references about evolution. Appropriate education standards of evolution theory require universal content; thus, it can be understood in biological, pedagogical and social contexts (Anderson, 2007; Kampourakis, \& Zogza, 2008). The results of this research revealed that the students, who had learned and comprehended the mechanisms of evolution, types of speciation, macro- and micro-evolution, genetic drift, and its role in evolution and allele frequency change in populations, had different opinions about evolution. This positive change that occurred in the opinions of the students after taking such an extensive evolution training course is also in line with the ideas of Sinatra, Southerland, McConaughy \& Demastes (2003). Furthermore, Sinatra, Southerland, Mc Conaughy and Demastes (2003) stated that beliefs predominated in case of limited or superficial knowledge, whereas the opinions of students were affected after the knowledge level exceeded a certain level. Accordingly, it can be said that the knowledge level should exceed a threshold for the acceptance of evolution. Indeed, various researchers reported that the rejection ratio decreased as conceptual understanding increased (Glaze, \& Goldston, 2015(a); Nunez, Pringle, \& Showalter, 2012; Deniz, Donelly, \& Yilmaz, 2008; Deniz, \& Şahin, 2016). However, in addition to the studies revealing the positive relationship between the understanding of evolution and its acceptance (Deniz, Donelly, \& Yilmaz, 2008; Rutledge, \& Warden, 2000; Lawson, \& Worsnop, 1992; Akyol, Tekkaya, Sungur, \& Traynor, 2012; Athanasioua, Katakosb, \& Papadopoulouc, 2012), there are also those finding no relationship between them (Bishop, \& Anderson, 1990; Sinatra, Southerland, Mc Conaughy, \& Demastes, 2003; Blackwell, Powell, \& Dukes, 2003; McKeachie, Lin, \& Strayer, 2002).

Another result of the current research is that there was quite a high ratio of the students who described evolution as a change, and thus were considered to have superficial knowledge about it (Table 1). Of all the students, 35.79\% had 
superficial knowledge about evolution and the majority describing it with superficial knowledge (53 students) were those who had not taken the evolution course. The fact that the students having superficial knowledge about evolution described evolution as a change does not reveal that they accept evolution; it only shows that they can describe it. Similarly, according to Mpeta, Villiers and Fraser (2015), to be informed about evolution does not mean that the concept is accepted.

According to the findings of the current research, students who had taken the evolution course described evolution from the perspective of high-level knowledge. The statements evaluated under "Evolution is the effort to understand the natural world" theme (students 9-13) were only expressed by the students who had taken evolution course, and this formed $12.11 \%$ of the students (Table 1). Describing evolution as the effort to understand the natural world requires high-level cognitive knowledge and was the aim to be achieved at the end of this course. This outcome may both show that the evolution mechanism was understood, and that these students possessed a positive attitude toward evolution. On the other hand, the lack of this awareness among the students who had not taken the course indicates the importance of comprehending evolutionary biology in relation to understanding biology. Moreover, the diversity of living beings being a result of the evolution and the interpretations associating evolution with the diversity of living beings were only made by the students who had taken the evolution course. Teaching the diversity of living beings is sufficient for neither biology nor science education. What should be comprehended is that evolution is the reason for the diversity.

The understanding of the evolution of populations is one of the major topics required to understand evolution, since without an understanding of this subject, natural selection remains only as a definition in students' mind. Understanding the evolution of populations and speciation mechanisms are the most basic issues describing how evolution takes place. In the current study, $8.42 \%$ of the students presented statements that explained evolution through the change of populations or speciation (students 14-16). Similarly, the majority of the students who mentioned population and speciation were those who had taken the evolution course. The presence of the students who explained evolution with the gene frequency of the populations is particularly important since it shows that evolution is completely comprehended by some of the students. The understanding of natural selection and adaptation represents the basic level of understanding evolution. The distribution of the students who explained evolution through natural selection and adaptation was balanced between the students who had taken the course and those who had not (Table 1). Students who had not taken this course also had an idea about this issue, which may show that these topics are covered within secondary education. The majority of the students, who associated evolution with genetics and who defined evolution as the main reason for diversity, were those who had taken the course. It has been reported that there is a relationship between students' content knowledge acquisition about evolution and their scientific process skills, belief systems and attitude toward evolution (Lawson, \& Weser, 1990). On the other hand, Cobern (1994) underlined an important aspect that is neglected on evolution training. He stated that there was a prevalent idea that if a student understood evolution, they would believe in evolution as well; however, even though understanding and believing are associated according to the constructivist approach, they are different subjects. In this case, it should be noted that although students who had taken the evolution course described evolution with high-level knowledge, this may not mean that they had accepted evolution. However, the reduction in the complete rejection ratio and description of evolution with high-level knowledge may show that their prejudice toward evolution had decreased. It is logical to assume that acquiring comprehensive information about the nature and process of a scientific theory may improve the understanding of evolution theory and encourage the acceptance of its scientific validity (Akyol, Tekkaya, Sungur, \& Traynor, 2012).

One of the major results of the current research is that on completion of the evolution course, students recognized that they were previously misinformed about evolution. Some of the students realized that evolution was not as simple as shown in the media and in the books, and some others even stated that their misinformation about evolution had been corrected (students 24-27). This shows that media and unscientific sources are effective in planting misinformation about evolution into society. Moreover, this result also shows that students may distinguish scientific and unscientific sources only after receiving accurate and adequate education related to this issue. In addition, it shows that correct and sufficient content is effective in providing an understanding of evolution and eliminating wrong attitudes and prejudices about evolution. Another study by Tekkaya, \& Kılıç, (2012) also supported our findings, revealing that students developed a positive attitude towards evolution after taking the course; in addition, they saw the course both interesting and necessary to understand the nature and themselves. The same study also revealed that students were did not accept evolution before, but after taking the course, they recognized the importance of evolution education (Tekkaya, \& Kılıç, 2012), However, the relationship between understanding and accepting evolution is not yet completely formulated (Deniz, Donelly, \& Yilmaz, 2008).

In this study, it was also found that some students accepted that minor changes might occur in living beings, which they thought might be related to evolution. On the other hand, some pre-service teachers stated that the evolution of living beings, especially humans, was not possible. Their perception of evolution was only related to the ape-descendance of 
humans, which has also been revealed in other studies (Blackwell, Powell \& Dukes, 2003; Töman, Karataş, \& Çimer, 2014). This may be because they fear that by accepting this change in perception, they will lose their existing beliefs.

In order for students to learn the theory of evolution, the pedagogical, intellectual and social aspects of their education should be completely taken into consideration. What is needed to ensure the progress and intellectual development of the students in relation to this issue is to see evolution as scientific knowledge and emphasize the intellectual development of the students in relation to the topic, rather than developing curriculum, material and education approaches (Anderson, 2007). In order to understand complex systems, such as evolution, students need to improve their scientific comprehension by blending scientific knowledge with thinking and reasoning skills (Crawford, Zembal-Soul, Munford, \& Friedrichsen, 2005). The teaching of evolution is not a phenomenon that can be simply achieved after a 14-week course. The intellectual background of the students, their social structure, having a sense of curiosity, and being open to new ideas are very important (Sinatra, Southerland, Mc Conaughy, \& Demastes, 2003; Deniz, Donelly, \& Yilmaz, 2008; Deniz, \& Şahin, 2016; Anderson, 2007). In addition to all these aspects, a better formation will occur in the mind of the students by supporting them with deeper and more specific knowledge related to evolution, such as the evolution of the genome, organelle genomes, chromosomes, and their use in systematics. It is obvious that a 14-week evolution course will not be sufficient for the students to understand all of these elements. To provide the time required to cover all the topics, it would be useful for the evolution course to be held over two semesters or to increase the number of course hours in a week. Giving this education to all biology and science pre-service teachers may allow for the correction of the misinformation about evolution and understanding the scientific foundations of evolution in both Turkey and the world.

Scientific knowledge is too precious to be a tool of some communities, for the ideologies of belief or disbelief. The elimination of social conflict concerning evolution will be possible only with appropriate and complete evolution education that does not contain jurisdictions about moral values. Removing prejudices and building knowledge require both sensitivity and experience. As with other sciences, evolutionary biology cannot be used to judge beliefs about morality and ethics. It can be used neither to answer theological questions nor to deny them (Futuyma, 2008). Thus, it is important to provide evolution education by taking sensitivities into account in a science-focused manner. It is fundamental to increase the number of sources that include accurate scientific information and facilitate access to these sources. It is also important to raise pre-service teachers to an intellectual level at which they can distinguish right and wrong sources of information.

Research indicates that accurate and unbiased evolution education should be provided as early as possible within the education system. Postponing evolution education until after high school causes many problems because some students do not continue to university education, whereas others do not take a biology course in university, and even if they study biology, evolution is not necessarily included; thus, many students never encounter this topic in an academic environment. In particular, in teacher education, it has been stated that evolution theory should be given as a uniting theme to ensure sufficient understanding of evolution within teacher education (Nunez, Pringle, \& Showalter, 2012). Evolution is an issue that can be used very effectively in understanding the nature of science (Anderson, 2007), and it is important to raise pre-service teachers who evaluate evolutionary knowledge from a scientific perspective based on scientific data and taking the scientific data into account. Since individuals raised by the teachers represent the future of society, it is essential for public officials as one of the stakeholders of education to understand scientific principles to make healthy decisions. As science and technology progresses, problems will continue to emerge. The formation of a perspective that will allow for the solving of problems, such as acid rain, destruction of forests, the Human Genome Project, recombinant DNA research, genetic engineering, nuclear power plants, and transportation and storage of hazardous waste (Smith, Siegel, \& McInerney, 1995) in the public will only be possible in the hands of the teachers raised in this way.

\section{Appendix:}

In my opinion, evolution

Student 1: ... is nonsense. There is no such thing as evolution, because Allah does everything he wants. We are not humans coming from monkeys; we came from the soil and we will return to the soil.

Student 2: ... is a controversial opinion of Darwin. It is a completely wrong idea, because the divine Creator, Allah (SWT), created the universe as a unique beauty. Human is a unique entity; it is a miracle of Allah (SWT), who creates from nothing.

Student 3: ... does not exist, because containing a few correct sentences is not sufficient to accept correctness. There is no room for chance in the world. Everything has been created for a reason.

Student 4: ... is the change of things over time, but Darwin made it up, because ape-descendance is absurd. I don't 
believe there would be very significant changes over time. Maybe small changes might occur.

Student 5: ... will continue forever and ever, because it is essential for the development of the world and for the continuation of life.

Student 6: ... is the process of change in living beings, which lasts for many years, because the change of living beings does not occur in a short time.

Student $7: \ldots$ is the change occurring in living beings over time, because living beings are constantly changing.

Student $8: \ldots$ is the change that occurs over a long time, because the observations are based on that.

Student 9: ... is the scientific discipline effort to explain the change, destruction and formation of living beings through the processes occurring since the formation of the world. Evolution is important because it allows us to understand living beings today.

Student $10: \ldots$ is the change of the living beings that has occurred until today. Everybody should acquaint themselves with this issue, because we should know how living beings and nature have come into existence.

Student 11: ... is the foundation of science, because the events of the universe happen through evolution.

Student 12: ... allows us to interpret the events on earth, because everything is a whole and affects each other.

Student 13: ... can be ignored during the course of life, a statement such as "there is no evolution" can be pronounced, but although evolution is not observed during our life cycle, it allows us to understand the reason of many events that occurred over a long period of time. This is evolution.

Student 14: ... is the differentiation of species over time to create new types of species, because living beings had to be diversified and adapted to the earth when they switched from living in water to living on land.

Student $15: \ldots$ is the changes that occurred in living forms for particular reasons. Because of migration, mutation and mating factors, species differentiate and create new species in due course.

Student 16: ... is the novelty of the changes of living beings, because we learned about different species. I learned the rules through which these species have changed.

Student $17: \ldots$ is an inevitable and continuous process of adaptation of living beings, because as the earth and living conditions change, living beings are obliged to adapt to continue their lives.

Student 18: ... is a journey to adaptation, because those who adapted better through natural selection could survive.

Student 19: ... is differentiation, because diversity increases through differentiation.

Student 20: ... is the scientific discipline revealing that living beings coming from a common ancestor, because it is obvious that living beings are diversified and developed as a tree, as the trunk and branches of a tree since old ages.

Student 21: ... is a biological process and the increase of biological diversity, because some species were eliminated whereas some of them survive through adaptation and natural selection.

Student 22: ... is the changes in the genes of species depending on the environment and climate, because every living being will evolve according to the needs, and these changes are transferred to the descendants.

Student 23: ... is changing, because change occurs continuously for environmental or genetic reasons.

Student $24: \ldots$ is not as simple as mentioned in the media or ordinary books because it occurs after a magnificent process that requires many stages and millions of years.

Student $25: \ldots$ is the logical explanation of the things that happen even though they are called impossible because the content of the course I took made me think of these.

Student 26: ... is a course that I listened to with interest and pleasure, because the misinformation that I had up to then was corrected and I learned many new things.

Student 27: ... course informed me and brightened my horizons because my head was filled with wrong information about the evolution process.

Student 28: ... is the biggest and most beautiful event, because I think it is the field that interests me the most in biology.

Student 29: ... is the idea of Darwin, because we were taught that evolution is the idea of Darwin.

Student $30: \ldots$ is the science discipline advocating that humans are ape-descendants, because evolution is change.

Student $31: . .$. is Darwin; I remember the passage from ape to human. 
Student 32: ... is nonsense. There is no such thing as evolution because Allah does everything he wants. We are not humans coming from monkey; we came from the soil and we will return to the soil.

Student 33: ... is the change of things over time, but Darwin made it up because ape-descendance is absurd. I don't believe there would be very significant changes over time. Maybe small changes might occur.

Student $34: \ldots$ is the idea of Darwin, a rumor about apes becoming human through evolution, because it is usually described that way".

\section{References}

Abrie, A. L. (2010). Student teachers' attitudes towards and willingness to teach evolution in a changing South African environment. Journal of Biological Education, 44(3), 102-107. https://doi.org/10.1080/00219266.2010.9656205

Akyol, G., Tekkaya, C., Sungur, S., \& Traynor, A. (2012). Modeling the interrelationships among pre-service, science teachers' understanding and acceptance of evolution, their views on nature of science and self-efficacy beliefs regarding teaching evolution. Journal of Science Teacher Education, 23, 937-957. https://doi.org/10.1007/s10972-012-9296-x

Alters, B. J., \& Nelson, C. E. (2002). Perspective: Teaching evolution in higher education. Evolution, 56(10), 1891-1901. https://doi.org/10.1111/j.0014-3820.2002.tb00115.x

Amanda, L., Glaze, A. L., \& Goldston, M. J. (2015). Science teaching and learning of evolution: a critical review of the literature 2000-2014. Science Education, 99(3), 500-518. https://doi.org/10.1002/sce.21158

Anderson, R. D. (2007). Teaching the theory of evolution in social, intellectual and pedagogical context. Science Education, 91, 664-677. https://doi.org/10.1002/sce.20204

Apaydin, Z., \& Sürmeli, H. (2009). Undergraduate students' attitudes towards the theory of evolution. Elementary Education Online, 8(3), 820-842. http://apbs.mersin.edu.tr/files/hsurmeli/Publications_011.pdf

Athanasioua, K., Katakosb, E., \& Papadopoulouc, P. (2012). Conceptual ecology of evolution acceptance among Greek education students: the contribution of knowledge increase. Journal of Biological Education, 46(4), 234-241. https://doi.org/10.1080/00219266.2012.716780

Barnes, M. E., \& Brownell, S. E. (2016). Practices and perspectives of college instructors on addressing religious beliefs when teaching evolution. CBE-Life Sciences Education, 15, 1-19. https://www.ncbi.nlm.nih.gov/pubmed/27193289

Bishop, B. A., \& Anderson, C. W. (1990). Student conceptions of natural selection and its role in evolution. Journal of Research in Science Teaching, 27, 417-425. https://doi.org/10.1002/tea.3660270503

Blackwell, W. H., Powell, M. J., \& Dukes, G. H. (2003). The problem of student acceptance of evolution. Journal of Biological Education, 37(2), 58-67. https://doi.org/10.1080/00219266.2003.9655852

Cobern, W. W. (1994). Comments and criticism. Point: Belief, understanding, and the teaching of evolution. Journal of Research in Science Teaching, 31(5), 583-590. https://onlinelibrary.wiley.com/doi/abs/10.1002/tea.3660310511

Crawford, B. A., Zembal-Soul, C., Munford, D., \& Friedrichsen, P. (2005). Confronting prospective teachers' ideas of evolution and scientific inquiry using technology and inquiry-based tasks. Journal of Research in Science Teaching, 42(6), 613-637. https://doi.org/10.1002/tea.3660310511

Dee Goldson, J. M., \& Kyzer, P. (2009). Teaching evolution: Narratives with a view from three southern biology teachers in the USA. Journal of Research in Science Teaching, 46, 762-790. https://doi.org/10.1002/tea.20289

Deniz, H., \& Sahin, E. A. (2016). Exploring the factors related to acceptance of evolutionary theory among Turkish preservice biology teachers and the relationship between acceptance and teaching preference. Electronic Journal of Science Education, 20(4), 21-43. https://files.eric.ed.gov/fulltext/EJ1188097.pdf

Deniz, H., Donelly, L. A., \& Yilmaz, I. (2008). Exploring the factors related to acceptance of evolutionary theory among Turkish preservice biology teachers: Toward a more informative conceptual ecology for biological evolution. Journal of Research in Science Teaching, 45(4), 420-443. https://doi.org/10.1002/tea.20223

Dobzhansky, T. (1973). Nothing in biology makes sense except in the light of evolution. The American Biology Teacher, 35, 125-129. https://doi.org/10.2307/4444260

Freeman, S., \& Herron, J. C. (2002). Evrimsel Analiz, Ankara: Palme Yayınc1lık.

Futuyma, D. J. (2008). Evrim, Ankara: Palme Yayıncılık.

Glaze, A. L., \& Goldston, M. J. (2015a). U.S. Science teaching and learning of evolution: A critical review of the 
literature 2000-2014. Science Education, 99(3), 500-518. https://doi.org/10.1002/sce.21158

Glaze, A. L., Goldston, M. J., \& Dantzler, J. (2015b). Evolution in the southeastern USA: Factors influencing acceptance and rejection in pre-service science teachers, International Journal of Science and Mathematics Education, 13, 1189-1209. https://doi.org/10.1007/s10763-014-9541-1

Hameed, S. (2008). Bracing for Islamic creationism. Science, 322, 1637-1638. https://doi.org/10.1126/science.1163672

Kampourakis, K., \& Zogza, V. (2008). Preliminary evolutionary explanations: A basic framework for conceptual change and explanatory coherence in evolution. Science and Education, 18, 1313-1340.

https://doi.org/10.1007/s11191-008-9171-5

Kim, S. Y., \& Nehm, H. R. (2011). A cross-cultural comparison of Korean and American science teachers' views of evolution and the nature of science. International Journal of Science Education, 33(2), 197-227. https://doi.org/10.1080/09500690903563819

Kurt, H., Ekici, G., Aktaş, M., \& Aksu, O. (2013). On the concept of “respiration”: Biology student teachers' cognitive structure and alternative conceptions. Educational Research and Reviews, 8(21), 2101-2121. https://eric.ed.gov/?id=EJ1017587

Lawson, A. E., \& Weser, J. (1990). The rejection of nonscientific beliefs about life: Effects of instruction and reasoning skills. Journal of Research in Science Teaching, 27(6), 589-606. https://doi.org/10.1002/tea.3660270608

Lawson, A. E., \& Worsnop, W. A. (1992). Learning about evolution and rejecting a belief in special creation: Effects of reflective reasoning skill, prior knowledge, prior belief and religious commitment. Journal of Research in Science Teaching, 29, 143-166. https://doi.org/10.1002/tea.3660290205

Lerner, L. S. (2000). Good and Bad Science in US schools, Nature, 407, 287-290. https://doi.org/10.1038/35030204

McKeachie, W. J., Lin, Y. G., \& Strayer, J. (2002). Creationist vs. evolutionary beliefs: Effects on learning biology. The American Biology Teacher, 64(3), 189-192. https://doi.org/10.1662/0002-7685(2002)064[0189:CVEBEO]2.0.CO;2

Merriam, S. B. (2009). Qualitative Research (third edition). USA: Jossey-Bass Publications.

Miles, M. B., \& Huberman, A. M. (1994). Qualitative data analysis. USA: Sage Publication.

Miller, J. D., Scott, E. C., \& Okamoto, S. (2006). Public acceptance of evolution. Science, 313, 765-766. https://doi.org/10.1126/science.1126746

Mpeta, M., Villiers, J. J. R., \& Fraser, W. J. (2015). Secondary school learners' response to the teaching of evolution in Limpopo province, South Africa. Journal of Biological Education, 49(2), 150-164. https://doi.org/10.1080/00219266.2014.914555

Nadelson, L. S., \& Southerland, S. (2012). A more fine-grained measure of students' acceptance of evolution: development of the inventory of student evolution acceptance-I-SEA. International Journal of Science Education, 34 (11), 1637-1666. https://doi.org/10.1080/09500693.2012.702235

Nunez, E. E., Pringle, R. M., \& Showalter, K. T. (2012). Evolution in the Caribbean classroom: A critical analysis of the role of biology teachers and science standards in shaping evolution instruction in Belize. International Journal of Science Education, 34(15), 2421-2453. https://doi.org/10.1080/09500693.2012.700529

Patton, M. Q. (1990). Qualitative Evaluation and Research Methods (second edition). USA: Sage Publications.

Peker, D., Cömert, G. G., \& Kence, A. (2010). Three decades of anti- evolution campaign and its results: Turkish undergraduates' acceptance and understanding of the biological evolution theory. Science and Education, 19(6-8), 739-755. https://doi.org/10.1007/s11191-009-9199-1

Rutledge, M. L., \& Warden, M. A. (2000). Evolutionary theory, the nature of science and high school biology teachers: Critical relationships. American Biology Teacher, 62, 23-31. https://doi.org/10.1662/0002-7685(2000)062[0023:ETTNOS]2.0.CO;2

Sinatra, G. M., Southerland, S. A., Mc Conaughy, F., \& Demastes, J. W. (2003). Intentions and beliefs in students' understanding and acceptance of biological evolution. Journal of Research in Science Teaching, 40, 510-528. https://doi.org/10.1002/tea.10087

Smith, M. U., Siegel, H., \& Mc Inerney, J. D. (1995). Foundational issues in evolution education. Science \& Education, 4, 23-46. https://doi.org/10.1007/BF00486589

Taskin, Ö. (2013). Pre-service science teachers' acceptance of biological evolution in Turkey. Journal of Biological Education, 47(4), 200-207. https://doi.org/10.1080/00219266.2013.788540 
Tekkaya, C., \& Kılıç, D. S. (2012). Pre-service biology teachers' pedagogical content knowledge regarding teaching evolution. Hacettepe University Journal of Education, 42, 4006-4017. https://doi.org/10.1007/s11191-009-9204-8

Thagard, P., \& Findlay, S. (2010). Getting to Darwin: Obstacles to accepting evolution by natural selection. Science \& Education, 19(6), 625-636. https://doi.org/10.1007/s11191-009-9204-8

Tidon, R., \& Lewontin, R. C. (2004). Teaching evolutionary biology. Genetics and Molecular Biology, 27(1), 124-131. https://doi.org/10.1590/S1415-47572004000100021

Töman, U., Karataş, F. Ö., \& Çimer, S. (2014). Analysis of the science and technology preservice teachers' opinions on teaching evolution and theory of evolution. Journal of Educational and Instructional Studies in the World, 4(1), 43-52. https://files.eric.ed.gov/fulltext/ED566245.pdf

Yıldırım, A., \& Şimşek, H. (2008). Sosyal Bilimlerde Nitel Araştırma Yöntemleri, Ankara: Seçkin Yayıncılık.

Yilmaz, F. (2016). Evolution perception with metaphors. Universal Journal of Educational Research, 4(4), 812-820. https://doi.org/10.13189/ujer.2016.040418

\section{Copyrights}

Copyright for this article is retained by the author(s), with first publication rights granted to the journal.

This is an open-access article distributed under the terms and conditions of the Creative Commons Attribution license which permits unrestricted use, distribution, and reproduction in any medium, provided the original work is properly cited. 